This is an electronic reprint of the original article. This reprint may differ from the original in pagination and typographic detail.

Author(s): Carolan, Fergal; Kyppö, Anna

Title: $\quad$ Teaching process writing in an online environment

Year: $\quad 2015$

Version:

Please cite the original version:

Carolan, F., \& Kyppö, A. (2015). Teaching process writing in an online environment. In J. Jalkanen, E. Jokinen, \& P. Taalas (Eds.), Voices of pedagogical development : expanding, enhancing and exploring higher education language learning (pp. 13-30). Research-publishing.net. https://doi.org/10.14705/rpnet.2015.000285

All material supplied via JYX is protected by copyright and other intellectual property rights, and duplication or sale of all or part of any of the repository collections is not permitted, except that material may be duplicated by you for your research use or educational purposes in electronic or print form. You must obtain permission for any other use. Electronic or print copies may not be offered, whether for sale or otherwise to anyone who is not an authorised user. 


\section{Teaching process writing in an online environment}

\section{Fergal Carolan ${ }^{1}$ and Anna Kyppö ${ }^{2}$}

\section{Abstract}

$\mathrm{T}$ his reflective practice paper offers some insights into teaching an interdisciplinary academic writing course aimed at promoting process writing. The study reflects on students' acquisition of writing skills and the teacher's support practices in a digital writing environment. It presents writers' experiences related to various stages of process writing, their growing awareness of becoming good writers but also the constant struggle with common writing problems. Preconceived attitudes towards the process of writing provide further obstacles for students to overcome in an interdisciplinary and intercultural learning environment. A writer often overcomes the barriers to effective writing by acquiring strategies for independent, self-directed learning. Course experiences may help teachers develop efficient writing courses for the new language learning environments and thus to promote students' academic writing competence.

Keywords: process writing, self-directed learning, language learning environments, common writing problems.

\section{Background}

This case study offers some insights into teaching an interdisciplinary academic writing course aimed at promoting process writing. In addition to the description

\footnotetext{
1. Language Centre, University of Jyväskylä, Finland; fergal.carolan@jyu.fi

2. Language Centre, University of Jyväskylä, Finland; anna.kyppo@jyu.fi
}

How to cite this chapter: Carolan, F., \& Kyppö, A. (2015). Teaching process writing in an online environment. In J. Jalkanen, E. Jokinen, \& P. Taalas (Eds), Voices of pedagogical development - Expanding, enhancing and exploring higher education language learning (pp. 13-30). Dublin: Research-publishing.net. doi:10.14705/rpnet.2015.000285 
of the course content and the learning space, the study reflects on students' acquisition of writing skills and the teacher's support practices in an online learning environment.

The English intermediate academic writing course is an elective, blended course (4 ECTS credits) offered by the University of Jyväskylä Language Centre in the autumn and spring terms. For over one decade, the course has been an essential part of the learner pathway for language and communication skills for study purposes across the university. The history of the course dates to 2003, when the web-based learning platform Optima was adopted and the English academic writing course became one of the first pilot projects aimed at the efficient use of digital environments for language teaching and learning. Due to the immense popularity of the course - the roots of which were undoubtedly in the growing need for tailored writing courses aimed at the development of academic writing - the course was offered for two levels: basic and intermediate. At the same time, the course became one of the Language Centre's action research projects aimed at the enhancement of independent, autonomous learning.

\section{Writing process or process writing?}

As one of the main goals of the academic writing course is to develop the students' skills in the process of writing and the nature of the writing course is process-like, this section attempts to clarify the concepts of the writing process and process writing.

In this context, the writing process involves teaching the students how to write in a variety of genres and how to incorporate academic writing conventions into their texts. The course has a number of special focuses: explicitness (i.e. signalling and signposting the ideas in the text), responsibility, providing supporting arguments for claims, properly acknowledging the sources of the ideas presented in the text, and the shift from informal to formal language. The objective is to make the students fully aware of the danger of plagiarism and to provide them with the tools to avoid it. 
Raimes and Miller-Cochran (2014) perceive the process of writing as focusing on content, fluency, personal voice and revision. Because writing always implies a process, instead of the term process writing she suggests the term the process approach to teaching writing. A process approach can be used with any content (e.g. academic, personal, literature). Seow (2002), however, considers process writing to be more than a writing process approach to teaching writing. $\mathrm{He}$ proposes the writing process to be an activity that broadly comprises the stages of planning, drafting (writing), revising (redrafting) and editing. Process writing, on the other hand, is seen as "a program of instruction which provides students with a series of planned learning experiences to help them to understand the nature of writing at every point" (Seow 2002: 316). In addition, process writing incorporates three other highly important skills: responding (sharing), evaluating and post-writing, which comprises re-reading the text for the logical structures and cohesion, eliminating the redundant text and proofreading for spelling, grammar and vocabulary.

Even though this course follows the basic steps of the writing process, it also maintains its process-like nature. The course is built on the spiral method of learning (Veladat \& Mohammadi 2011), according to which after acquiring the basic knowledge, students expand on their skill level through 'learning by doing', and they construct the new knowledge. In the context of this academic writing course, students acquire the basic knowledge and become familiar with various genres of academic writing. After producing shorter texts, they proceed towards longer, more sophisticated ones. Revisiting the basic concepts of academic writing and building on the previously acquired knowledge results in an increase in both their learning awareness and in their confidence of themselves as writers.

As they explore the phenomena of academic writing, they progress from the topic sentence to the paragraph, from the paragraph to the essay and so on. They expand their writing skill level with each learning session. The class proceeds through the writing stages as a group, with postwriting consisting of teacher and peer feedback. Multiple forms of feedback generally results in a new draft. To support the idea of the above mentioned learner portfolio, 
learners are expected to save everything they create (e.g. drafts) or obtain (e.g. peer and teacher feedback) in order to be able to reflect on the overall process of writing.

\section{Course content and demography}

This section provides basic demographics and the information about the content, modes and expected outcomes of the course.

The main focus of the course is on the development of independent writing skills and the enhancement of self-directed learning. After the completion of the course, students are expected to have developed their academic writing skills, especially the skills of process writing, and enhanced their skills of independent, self-directed learning. They are also expected to have developed their skills in giving and receiving peer feedback on writing and reflecting on their own writing and learning process.

The course participation is open to all university students - Finnish and international degree and short-time (exchange) students - who wish to develop their writing skills. In addition, postgraduate students may participate in the course. Course participants are expected to have the proficiency level B2-C1 (CEFR 2009) in English. In addition to 10-14 contact lessons, the students are expected to participate in the online interaction related to the writing assignments and respond to continuous teacher and peer feedback to the extent of approximately 20 hours. They are assessed according to their participation and completion of the writing assignments.

\section{Learning space and learner portfolio}

This section introduces the web-based learning platform Optima and the course workspace from the viewpoint of the optimality and efficiency of the learning environment. 
Optima is an adaptable web-based learning platform that supports independent, self-directed learning. It enables the sharing of various types of resources, such as documents, websites and audiovisual materials. It also offers various interactive functions, such as chatting, a diary, a collaborative writing platform and commenting and feedback functions. Malone (2012), in his articles on second-language acquisition, presents a social interactionist view, which emphasises the importance of an optimal learning environment. Such a learning environment provides the language learners with multiple opportunities to use the target language and may serve as a uniting factor (i.e. a student works alone but is still with the others). It therefore facilitates the acquisition of a common learning experience. The Optima learning platform fulfils this definition an optimal learning environment.

The course workspace is composed of several folders, which include all the course materials and activities. The main writer's folder contains the course plan and resources (e.g. writing-related websites, teacher materials and course assignments). Course participants have their own folders for mapping their learning outcomes through the peer and teacher feedback they give and receive and by reflecting on their writing process.

The course learning materials contained in the main folder and subfolders follow the basic steps of the writing process: planning, prewriting, brainstorming and outlining, drafting, revising and editing. The nature and technological properties of the Optima platform offer the learners the possibility to build a learner portfolio. Learner folders partially follow the structure of a personal learning portfolio (Morrison 2013), which involves a personal profile. A profile consists of various elements, including a student's introduction, course expectations, learning/writing needs, a record of the course (e.g. assignments, reflections, peer and teacher feedback), and the student's personal space for complementary writing or storing of learning- and writing-related resources (e.g. websites, media materials, blogs).

According to Barrett (2005), a traditional learner portfolio includes collecting, selecting, reflecting, projecting and celebrating. In the context of this course, 
collecting and selecting are related to the completion of writing assignments and other writing-related materials. The focus of reflecting is on one's own writing process, and projecting is related to the learner's self- and peerevaluation, collaborative writing and group brainstorming. Celebrating refers to the final evaluation of one's achievements as well as the final assessment of the course.

\section{Course design and content}

This section offers insight into the course design and explains the content of the writer's folder, which, in its structure, reflects and supports the writing process.

The main folder consists of the following named subfolders: (1) first writing assignments, (2) academic writing, (3) critical reading and writing, (4) paragraph and essay, (5) research reporting, (6) summarising and paraphrasing, (7) referencing and incorporating sources, and (8) revising. In addition, the folder offers links to various writing-related websites and online tools, such as the Purdue University Online Writing Lab (OWL 2013), the UVIC Writer's Guide (1995) and Using English for Academic Purposes, Andy Gillett's (2014) online guide for students in higher education. There are also web materials related to the specific problems of academic writing (e.g. writing and grammar, punctuation in academic writing). In addition to information on writingsupportive skills, such as summarising, paraphrasing and the instructions on citing and incorporating sources into one's text (e.g. the IEE Citation Style Guide and Using English for Academic Purposes), the writer's folder provides guidelines on how to give peer feedback, what to focus on when reading texts written by others, and how to respond to the feedback received. This section continues with a description of how the course introduces students to academic writing as a genre and to the initial stages of the writing process.

The first of the subfolders, first writing assignments, is also the most important. It offers the initial writing assignments, one of which helps students and the 
teacher get to know each other and establish the course goals. Almost all of them want to learn 'how to write', 'how to produce academic texts', 'to write essays in English' and so on. The first written assignment is called 'Am I a writer?', and it is aimed at the enhancement of creative thinking and exploring multiple uses of an image in writing. Its purpose is to develop strategies for fluency, speed and the free flow of ideas. Students are asked to look at their computer and write about it for 15 minutes. They do not need to worry about spelling, grammar or style. The only rule is that they may not stop writing. After 15 minutes they read their texts in class. The results are often surprising. The texts are usually long and fluent, the language is rich in idiomatic expressions and mostly correct. The purpose of this rapid-writing task is to encourage the students to write and at the same time, to reveal their real writing abilities. The assignment is generally welcomed by the students, because it is both encouraging and fun.

The focus of the academic writing subfolder is on the basic features of academic writing. It also offers sample texts that reveal the variety of academic genres. The structure of academic texts is best demonstrated by scholarly articles related to the students' fields of study, because these generally follow a standard pattern: an introduction providing background information on the subject (general statements on the topic, specific details about a sub-area, review of relevant literature and other research in the field, and a research niche), the problem (i.e. a thesis statement), procedures and methods (description of the methods used in the research, data collection and analysis), results (reporting on the results), discussion (assessment of the results) and references (the cited literature). After getting familiar with the structure of academic texts, the basic steps of process writing are introduced: planning/brainstorming, prewriting, drafting (writing), revising, followed by editing and rewriting.

\section{The writing process, from paragraph to finished essay}

This section provides a step-by-step description of the writing process. The whole process is first demonstrated on the paragraph level. The main focus is 
on the structure of the paragraph and the topic sentence. The focus of paragraph writing is on exploring, in a concise manner the stated topic, evaluating the evidence, expounding on the idea, and creating an argument that concerns the idea/topic. Once this outcome is reached, the barrier to writing an essay is overcome.

After practicing different types of paragraphs - descriptive (static and process description), problem/solution, argumentative and persuasive - students begin to prepare an expository five-paragraph essay on a topic of their choice. The essay consists of an introductory paragraph, three supporting body paragraphs and a conclusion. Special focus is on the development of a thesis statement. The thesis statement is an assertion about the topic and it points to the purpose and direction of the paper, and thus it is important that the writers write one that is clear and concise. The major focus is on logical transitions between the paragraphs as well as on the evidential support of the arguments presented in the body (i.e. the main part of the text).

Students practise writing a problem-solving and argumentative expository essays before getting started with the essay related to their field of study. The prewriting stages are completed in pairs or small groups, and the writing itself is implemented individually, but students often benefit from the online area for collaborative writing. After completing the essay, feedback is given in pairs or small groups. Students are expected to reflect on the received feedback and implement the changes recommended by their peers. If the feedback is unclear or a writer does not understand a peer's comments, she may ask for clarification. When reviewing a colleague's essay, reviewing instructions are to be followed. These are targeted at the overall structure of the text (the introduction, body and conclusion), linguistic aspects (grammar and vocabulary), textual organisation (criteria of development, continuity, balance and completeness) and cohesion (use of linking words and phrases). Referring to sources and the relevancy of the topic is also taken into consideration. Rewritten texts (drafts) are reviewed by peers and the teacher. Generally two to three drafts are produced. Nevertheless, not all the students are capable of giving and receiving 
constructive feedback. For example, some students consider the peer feedback to be less professional than the teacher's feedback:

"Peer evaluation is not always good in my opinion. A classmate can give you small pieces of advice but it is very difficult to find one who really knows what to tell you in order to make your essay/paper better. For instance, I am not able to do it".

"The best part of the course was the teacher's constant feedback..."

For assigned topics, the online collaborative writing area may be used for brainstorming and writing. Students enjoy writing together, as they often claim. One of the benefits of the collaborative writing area is its accessibility. Writers do not have to give access to their readers, because comments are visible immediately upon entering the area. When students write together, ideas flow more rapidly and students may get the inspiration they seek from the previously written text. However, one of the disadvantages is that the area cannot be used simultaneously by more than one writer. So even though the final text is the product of the whole group, the text is written in the one-by-one method. One solution is simultaneous writing, everybody writing on the same topic, at the same time. However, the texts must be imported into the writing area and cohesively linked together. In the context of this study, the writing area has been used for text editing in small groups. Each group produced its own draft, which was then edited by other groups. Because all the texts may be displayed in the area, it is easy to compare them and search for some distinctive features of academic texts (e.g. the use of academic vocabulary, linking words, punctuation).

After the practice writing come the writing and revising stages. In these, students start to write an essay related to their field of study. One of the most difficult tasks is the choice of the topic. The topic is related to the student's field of study and its extent is six to seven standard pages including the references. The MA thesis writers and postgraduate students may write a research paper. The instructions for writing a research paper are available in the writer's folder 
and are usually specified by the teacher. As can be seen in the comments below, students value the possibility to write about their own studies and research topics:

"I enjoyed the fact that it was possible to cover the topics related to your own field of study in the assignments. If it had not have been possible to write the texts about the issues from my own field of study, I would have felt considerably less motivated to write".

"In my opinion, it was a good idea to write the final paper on my own research, because that has a purpose, it is not 'just' writing..."

Identifying the topic is often connected with the development of the thesis statement. Writing a focused statement is one of the greatest challenges for students. It should indicate the purpose, scope and direction of the paper while also previewing the sub-theses to follow and identifying the relationships between the pieces of evidence used to support of the writer's arguments. To break the barrier and let the ideas flow, the students may spontaneously tell their peers (or the teacher) what they want to write about. Asking some questions about the topic often helps the writer to organise ideas and create a solid statement. Brainstorming is implemented in small groups. To make the best of the peers' contribution, students create a mind map or poster for generating the ideas. They ask their colleagues for the feedback in the form of comments or questions on the statement related to the topic. If necessary, this process is repeated until a sufficient number of ideas is generated. Interestingly, the best ideas are not always generated during the brainstorming period.

The most productive step of the writing process is writing the first draft. This is the most time-consuming stage, but it is also the most rewarding. The first draft is generally followed by the second and sometimes even the third draft. Even though writing usually takes place offline (i.e. outside of class), students are often in the Optima learning environment either writing or retrieving information or just hanging out. In addition to regular face-to-face tutorials and online sessions, course participants spend time together outside of the class, which underlines the social aspect of the learning process. 
One of the most fruitful stages of the writing process is revising and editing. Revising (i.e. making the text sound better) includes organising the text, replacing informal non-academic terms with more formal academic ones, adding details, clarifying explanations and focusing on cohesion. Editing (i.e. making the text look better) means correcting spelling and punctuation as well as finalising the text layout. In this stage of the writing process, students talk about their texts with their peers and the teacher, which results not only in the improvement of the structure, but also in the clarification of the ideas presented in the paper and refinement of the writers' arguments and contrary evidence. This stage usually makes the students think about what they are doing and what they are writing about and thus promotes their skills of critical literacy:

"I believe I have made a progress as a writer. In the beginning of the course, writing in English demanded more effort and thinking. Writing now is more effortless and it comes fluently".

"I learned how to pay more attention to my writing. Maybe I earlier just wrote without thinking..."

This writing and thinking often resulted in rewriting. The aphorism on writing that 'writing is rewriting' is close to the reality. Or, as H. Shaw, the author of Errors in English and Ways to Correct Them (as quoted in Shope 2002: para. 1), says, "There is no such thing as good writing. There is only good rewriting".

\section{Student reflections}

Finally, at the end of the course, students are required to reflect on their writing progress and evaluate the course. Students' reflections relate most often to the process of process writing, writing topics, becoming academic writers, self-confidence in writing, course atmosphere, feedback (teacher and peer feedback) and the Optima learning environment. Some findings based on the students' excerpts from course reflections and course feedback forms are presented below. 
The process of writing was perceived as long, demanding and requiring patience and concentration, but all of the students considered the course to be useful for their future studies and working life:

"Now, as I look at the list of assignments in my folder, I realise that the course has been quite a long one, but that is what process writing takes. I feel I have improved as a writer. I did manage quite well before, but I have done most of my writing in Finnish. Getting more accurate in academic English writing has been the main learning experience for me in this course and these skills will be useful in the future".

"I have never written as much as I have on this course..."

They all valued the continuous teacher feedback and the pleasant atmosphere on the course. They believed that they made clear progress in academic writing and were optimistic about their writing in the future. Some praised the abundance of learning resources in Optima, but others would have preferred a more traditional learning environment:

"I think that Optima environment is adequate for the purpose of this course and it supported the learning process quite well. It was also nice to be able to exchange feedback and to be able to see the texts of other students".

"Optima works well, but there are too many folders and subfolders, which makes it exhausting to look for information. The common writing area was also hard to control or finish..."

The excerpts of students' reflections reveal that they take genuine pleasure in writing, despite the difficulties related mostly to searching for the appropriate academic vocabulary, struggling with structures and the impact of language interference:

"Sometimes I enjoyed writing, sometimes writing was difficult. I had no 
ideas or no clear structure. After writing for a while it went better but the beginning was always very difficult for me. My biggest problem is the translation from German into English. I translate directly. I should think more about the structure and not translate..."

"I enjoyed writing. I learned new things, like the correct essay structure. But it was difficult..."

Being able to write about one's own field of study in English was also a source of pleasure:

"Writing was somewhat boring because the paper did not allow the use of all kinds of expressions (e.g. rhetorical or humorous utterances). However, I enjoyed the feeling of being able to write about my field in foreign language. It was like exploring a new environment".

"Writing is a kind of therapy for me. I always feel good when I am writing. The best thing is when I realise that I can express my ideas in a foreign language. And I wrote the essay about my major subject..."

For some students, writing an essay was their first encounter with academic writing:

"I have become a better writer. I know I should have enough information about the topic and I have to learn more vocabulary. I made progress because this essay was the first academic essay that I wrote and I used academic language for the first time".

"I have learned important things about academic writing, for example, academic expressions and how to improve the paragraphs. I believe that information will be useful in the future".

"I think my writing skills have improved. I know now that I should avoid long sentences. The essay was a good exercise for practicing academic 
writing. In addition, the course provided me with lots of background information about writing an academic essay".

As mentioned earlier, one of students' frequent writing problems is a lack of self-confidence. The course not only contributed to the development of students' academic writing skills, but it also helped them to acquire self-confidence:

"I have learned how to use the academic language. Besides, I learned how to write an essay in a focused way. The intermediate academic writing course helped me to improve my writing skills to become more selfconfident in writing".

"My vocabulary and writing skills have absolutely developed. Thanks to the feedback, I learned about my writing problems related to grammar and structure".

"I learned about the structure of an essay. My academic skills got developed. This course helped me with academic writing. Moreover, I got rid of my worries about writing an essay".

\section{Teacher reflections}

This section opens a discussion about the so-called successful and less successful writers. Some of the barriers to successful writing are listed, as are some tips on how to overcome these barriers. Some of the students' ideas related to the impact of writing on their personal development are also introduced. Academic intermediate writing poses several challenges to the teacher, the greatest of which are the differences in learners' language proficiency and culture-related approaches to self-directed learning. Personal engagement, readiness to learn, motivation and above all, the urge to develop the learners' academic writing skills are often present. Nevertheless, it is up to the teacher to design a cooperative learning environment that motivates the students and facilitates their learning efforts. 
Course participants are expected to have the proficiency level B2-C1 (CEFR 2009) in English. They are expected to be able to produce various types of written texts and to demonstrate their capability to use the language in a variety of contexts:

\begin{abstract}
"Users at this level...should be able to produce written texts of various types, showing the ability to develop an argument as well as describe or recount events. This level of ability allows the user a certain degree of independence when called upon to use the language in a variety of contexts" (CEFR 2009³).
\end{abstract}

However, only a few students can perform to that level. The Finnish students often lack confidence in their own skills and the international students generally lack the writing experience. In addition, they are not familiar with the strategies of independent, self-directed learning. The digital learning platform itself poses a challenge:

"In the beginning I was confused because at my home university we don't have this kind of online work space. It was interesting though that after I got used to it (in a couple of weeks...maybe three), I realised how useful it is. We didn't have to print or write anything, because everything we needed to know was already there".

Furthermore, students can often feel overwhelmed when first surveying the course contents in Optima. When the course begins, students can see the full range of work that lies ahead of them. All of the course material, plus the wide range of assignments, are initially visible. Though this gives students a realistic impression of the time they will put into the course, some may find daunting the sight of all the course material at once. To counter this feeling, it is vital to reassure students of their abilities as writers from the first in-class meeting.

Confidence building is a key component, and many students experience a socalled eureka moment at some point. Students that lack the confidence to apply

3. Cited in Teaching Standards in Chile: B2 (Alte Level Three); retrieved from http://www.sccinternational.org/?p=82. 
their writing skills effectively overcome this barrier when they perceive that they have been given a system with which to write. Once these students discover their own personal writing process, they overcome their lack of confidence and develop as writers.

\section{Implications for the future}

The overall positive reaction of students to the digital learning platform is encouraging for its use in the future. As the classroom, and indeed the world, continue to become more technologically rich environments, it is only prudent that this course continues to develop along with modern technology. One perceived limitation of the course is the fact that it is currently taught in a computer lab. Computer labs, in some cases, can be at a premium. If, for example, the instructor is reliant on booking a computer lab for the course, it can limit the timetabling options for the course. While laptops and other devices are now in widespread use, students have been reluctant to bring their own devices to the classroom. As stated previously, many of the course participants are students on exchange. These students cite the poor condition of their devices and short battery life as the main reasons for their reluctance to use them in class. Perhaps in the future the use of tablet devices or similar technologies will become even more common and widespread, which might serve to negate this issue.

While considering the future of the course it is also important to reflect on how technology can detract from the writing process. Writing on a computer with a keyboard has a somewhat different dynamic to writing by hand with a pen or pencil. Excessive use of technology is likely to speed up the entire writing process, which is not necessarily a positive outcome. When they write by hand, students tend to take more time to consider what exactly they will include in each sentence. The extra time that a student spends writing by hand can be valuable in improving the content and quality of students' texts. For this reason, older writing methods should not be discarded while developing this course for the future. 
Similarly, the ease with which source material can be accessed online poses problems. If a student has to go to a library or archive to find source material, it takes much more time than if they access the same materials through online resources. That extra time spent travelling to the library and physically locating the source material can be crucial in a student's thought process. By physically locating source material for their work, the student has time to consider why they are getting that particular piece of information, how it is relevant to their topic and in what way they will incorporate it into their piece of text. It is vital that these elements of the thought process are not lost as the use of technology increases. This course will continue to develop in ways that preserve these crucial aspects of the writing process.

Optima has proved to be a functional interactive learning environment and an excellent platform for process writing. Its greatest benefit is its functionality, organising learning resources and making them easily accessible. The current version of Optima offers a wide variety of multimedia tools that can be incorporated seamlessly into the writing process. Simard (1997) has highlighted the changes multimedia environments bring to the writing process. In these environments, the writing process becomes the sum of various interactive processes that utilise a range of skills for a specific purpose. Even though the explicit purpose of our course has been the production of written academic texts, the course hopefully offers something deeper, namely, the intellectual excitement and pleasure of new learning experiences.

\section{References}

Barrett, H. C. 2005. Researching digital portfolios and learner engagement. White Paper. Retrieved from http://www.taskstream.com/reflect/whitepaper.pdf

CEFR (Common European Framework of Reference for Languages). 2009. Learning, teaching, assessment. A Guide for Users. Strasbourg: Language Policy Division.

Gillett, A. 2014. Using english for academic purposes. A guide for students in higher education. Retrieved from http://www.uefap.com/ 
Malone, D. 2012. Theories and research of second language acquisition. Reading for day 2, Topic SLA Theories. Bangkok: MLE WS.

Morrison, D. 2013. How to create a personal learning portfolio: students and professionals. online learning insights. Retrieved from http://onlinelearninginsights.wordpress. com/2013/01/30/why-students-need-personal-learning-portfolios-more-than-we-do/

OWL Purdue University Online Writing Lab. 2013. Retrieved from https:/owl.english. purdue.edu/ow1/resource/980/02/

Raimes, A. \& Miller-Cochran, S. K. 2014. Keys for writers. Boston: Wadsworth Cengage Learning.

Seow, A. 2002. The writing process and process writing. In J. C. Richards \& W. A. Renandya (eds.), Methodology in language teaching. An Anthology of Current Practice. Cambridge: Cambridge University Press, 315-320. doi:10.1017/CBO9780511667190.044

Shope, B. 2002. True writing is rewriting. Holly Lisle's Vision. A resource for writers. Retrieved from http://fmwriters.com/Visionback/Issue9/true.htm

Simard, J. 1997. The Writing process in a multimedia environment. The Technology Source. Retrieved from http://technologysource.org/article/writing_process_in_a_multimedia environment/

UVIC. 1995. Writer's Guide. Retrieved from http://web.uvic.ca/wguide/Pages/MasterToc. html

Veladat, F. \& Mohammadi, F. 2011. Spiral learning teaching method: Stair stepped to promote learning. Procedia - Social and Behavioral Sciences, 29, 1115-1122. doi:10.1016/j. sbspro.2011.11.345 


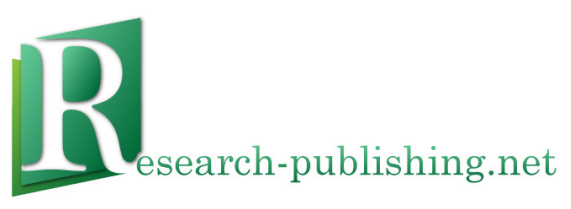

Published by Research-publishing.net, not-for-profit association Dublin, Ireland; Voillans, France, info@research-publishing.net

(C) 2015 by Research-publishing.net (collective work)

Each author retains their own copyright

Voices of pedagogical development - Expanding, enhancing and exploring higher education language learning Edited by Juha Jalkanen, Elina Jokinen, \& Peppi Taalas

Rights: All articles in this collection are published under the Attribution-NonCommercial -NoDerivatives 4.0 International (CC BY-NC-ND 4.0) licence. Under this licence, the contents are freely available online (as PDF files) for anybody to read, download, copy, and redistribute provided that the author(s), editorial team, and publisher are properly cited. Commercial use and derivative works are, however, not permitted.

\section{()ㅛ $\Theta \Theta$}

Disclaimer: Research-publishing.net does not take any responsibility for the content of the pages written by the authors of this book. The authors have recognised that the work described was not published before, or that it is not under consideration for publication elsewhere. While the information in this book are believed to be true and accurate on the date of its going to press, neither the editorial team, nor the publisher can accept any legal responsibility for any errors or omissions that may be made. The publisher makes no warranty, expressed or implied, with respect to the material contained herein. While Research-publishing.net is committed to publishing works of integrity, the words are the authors' alone.

Trademark notice: Product or corporate names may be trademarks or registered trademarks, and are used only for identification and explanation without intent to infringe.

Copyrighted material: Every effort has been made by the editorial team to trace copyright holders and to obtain their permission for the use of copyrighted material in this book. In the event of errors or omissions, please notify the publisher of any corrections that will need to be incorporated in future editions of this book.

Typeset by Research-publishing.net

Cover design by (C) Antti Myöhänen

ISBN13: 978-1-908416-25-4 (Paperback - Print on demand, black and white)

Print on demand technology is a high-quality, innovative and ecological printing method, with which the book is never 'out of stock' or 'out of print'.

ISBN13: 978-1-908416-26-1 (Ebook, PDF, colour)

ISBN13: 978-1-908416-27-8 (Ebook, EPUB, colour)

Legal deposit, Ireland: The National Library of Ireland, The Library of Trinity College, The Library of the University of Limerick, The Library of Dublin City University, The Library of NUI Cork, The Library of NUI Maynooth, The Library of University College Dublin, The Library of NUI Galway.

Legal deposit, United Kingdom: The British Library.

British Library Cataloguing-in-Publication Data.

A cataloguing record for this book is available from the British Library.

Legal deposit, France: Bibliothèque Nationale de France - Dépôt légal: septembre 2015. 